\title{
Toxicological effects of raw jack beans, bambara groundnuts and benne seeds on organs of cockerel
}

\author{
Akanji AM*, OE Fasina, AM Ogungbesan
}

Department of Animal Production, College of Agricultural Sciences, Olabisi Onabanjo University, Yewa Campus, Ayetoro, Ogun State, Nigeria

\begin{abstract}
The study was carried out to determine and compare the toxicological effects of raw jack beans (RJB), bambara groundnuts (RBG) and benne seeds (RBS) on organs of cockerels (Goldmine strain). Full fat soya was replaced with RJB, RBG and RBS at $25 \%$ and $50 \%$ levels, respectively. One hundred and forty (140) cockerels were randomly distributed into seven dietary groups in an eight week feeding trial. Antinutritional factors such as canavanine, haemagglutinin, trypsin inhibitor, tannin and phytate contents were analyzed in the plant seeds. At the end of eighth week, the birds were killed by cervical dislocation while the internal organs were quickly dissected out. The liver, kidney, pancreas and testis were thereafter preserved in $10 \%$ formalin solution. The tissues of the organs were trimmed, fixed in Bouin's fixative for $24 \mathrm{~h}$, embedded in wax, sectioned at $6 \mu \mathrm{m}$ with microtome and finally stained with haematoxylin and eosin for histopathological examination. The livers of the birds fed $25 \% \mathrm{RJB}$ and $50 \%$ RJB showed extensive multifocal and lymphocytic infiltration with necrosis of hepatocytes. Moreover, the pancreas of birds fed RBG and RJB based diets showed necrosis of glandular cells, lymphoid aggregates, thickening of the supporting stroma and multifocal interstitial lymphocytic infiltration. In the testes of birds fed $25 \%$ RJB and $50 \%$ RJB, there was extensive degeneration of the seminiferous tubular epithelia cells with widespread interstitial lymphocytic infiltrations of the stroma. The liver, pancreas, kidney and testes of birds fed RBS showed moderate lesions. It is concluded in this study that RJB showed more toxicity than RBG and RBS with respect to lesions in the organs, thus depicting a severe negative effect when fed to cockerels. There is therefore the need to detoxify the raw plant seeds with a view to enhancing their nutritive value in diets of cockerels
\end{abstract}

Key words: plant toxicology, cockerels, organs

Bangladesh Animal Husbandry Association. All rights reserved.

Bang. J. Anim. Sci. 2016. 45 (2): 18-23

\section{Introduction}

Legumes and oil seeds are important sources of protein and energy for farm animals respectively. Moreover, despite this nutritional significance, their inclusion in the raw form in diets of rats and chickens has been reported to cause growth depression, decreased protein digestibility and pancreatic enlargement (Essien and Udedibie, 2007).Studies carried out by Apata (1990) showed also that feeding of raw legumes to albino rats caused marked alterations in the normal activities of several hepatic and extra hepatic enzymes. There is no doubt that antinutritional factors in legumes such as lectins, trypsin inhibitors, tannin, cyanogenic glycosides and canavanine have been linked with disruption in normal metabolic activities in the body of an animal.
Grant et al., (1991) demonstrated that changes in metabolic activities and nutrient absorption in rats caused structural damage, malformations and visible lesions of organs. A prominent example of the lectins, concanavanine $A$, has been found to enhance shedding of the brush border membranes and decrease in villus length in rats (Russell et al., 2008). Also. canavanine has been reported to form a bond with proteins (L-canavanyl proteins) which lacks the capacity to form crucial ionic interactions, resulting in altered protein structure and function, which leads to cellular death (Bence and Crooks 2003). The feeding of raw lima beans by rats also disrupted intestinal microvilli (Aletor and Fetuga, 1988). An interference of lectins with the glycoproteins and glycolipids of the digestive tract coupled with several side effects on organs controlling immune functions, protein

*Corresponding author: drakanjiadetayo@yahoo.com 


\section{Plant toxicology on cockerel organs}

metabolism, enzyme activities and hormonal regulations were also reported by Olkowski et al. (2001). Apart from the natural toxic components of raw grain legumes, the intake of some artificial toxic compounds such as chromium (Sahin et al., 2001) and mycotoxins (Chowdhury and Smith 2004) have been reported to cause damage to body parts and metabolites of livestock animals. Apart from the effects of some of these toxic artificial compounds on growth of animals, the reproductive organs and semen production were also reported to be affected. Hence, this study was carried out to determine and compare the toxicological effects of raw jack beans, bambara groundnuts and benne seeds on organs of cockerels.

\section{Materials and Methods}

Dry and raw seeds of jack bean (Canavalia ensifirmis ( $L$ ) $D C$ ), bambara groundnuts (Vigna subterranean ( $L$ ) Vendc) and benne seeds (Sesamum indicum L.) were obtained from the Department of Agronomy, University of Ibadan, and the National Cereals Research Institute, Moor Plantation, Apata, Ibadan, South Western Nigeria.

\section{Chemical analyses}

Analytical methods of AOAC (1984) were used to determine the proximate compositions (Table 1) of raw jack beans, bambara groundnuts and benne seeds. Concentrations of lectins and trypsin inhibitor were determined using the haemagglutinin assay (Valdebouze et al, 1980) and a modified Kakade method (Van Oort et al.,1989) respectively. Tannin, oxalate and phytate contents were determined by the method described by Apata (1990). Canavanine content was determined by method described by Natelson and Bratton (1994)

\section{Experimental diets}

Seven (7) different diets were formulated for this experiment (Table 1). Raw jack beans, bambara groundnuts and benne seeds replaced full fat soybean meal at $25 \%$ and $50 \%$ levels in diets for adult cockerels. Minor adjustments were made in the ingredients to keep the diets isonitrogenous and isocaloric. All diets were supplemented with $1.5 \mathrm{~g} / \mathrm{kgDM}$ methionine because soybeans, jack beans and bambara groundnuts are known to be deficient in methionine. In addition, the diets containing the benne seeds were supplemented with $2.0 \mathrm{~g} / \mathrm{kgDM}$ of lysine to ensure that the amino acid was not limiting.

Table1. Composition of diets for cockerels (g/kgDM)

\begin{tabular}{|c|c|c|c|c|c|c|c|}
\hline & Control & $25 \%$ RJB & $50 \%$ RJB & $25 \%$ RBG & $50 \%$ RBG & $25 \%$ RBS & $50 \%$ RBS \\
\hline aize & 422.0 & 422.0 & 420.0 & 420.0 & 422.0 & 418.0 & 420.0 \\
\hline Full fat Soya & 180.0 & 135.0 & 90.0 & 135.0 & 90.0 & 135.0 & 90.0 \\
\hline Jack bean & - & 45.0 & 90.0 & - & - & - & - \\
\hline Bambara & - & - & - & 45.0 & 90.0 & - & - \\
\hline Benne & - & - & - & - & - & 45.0 & 90.0 \\
\hline Fish meal & 15.0 & 15.0 & 15.0 & 15.0 & 15.0 & 15.0 & 15.0 \\
\hline Wheat bran & 346.5 & 346.5 & 348.5 & 348.5 & 346.5 & 348.5 & 346.5 \\
\hline Bone meal & 20.0 & 20.0 & 20.0 & 20.0 & 20.0 & 20.0 & 20.0 \\
\hline Oyster shell & 10.0 & 10.0 & 10.0 & 10.0 & 10.0 & 10.0 & 10.0 \\
\hline Salt & 2.5 & 2.5 & 2.5 & 2.5 & 2.5 & 2.5 & 2.5 \\
\hline Premix & 2.5 & 2.5 & 2.5 & 2.5 & 2.5 & 2.5 & 2.5 \\
\hline DL methionine & 1.5 & 1.5 & 1.5 & 1.5 & 1.5 & 1.5 & 1.5 \\
\hline Lysine & - & - & - & - & - & 2.0 & 2.0 \\
\hline Total & 1000.0 & 1000.0 & 1000.0 & 1000.0 & 1000.0 & 1000.0 & 1000.0 \\
\hline Crude Protein (\%) & 16.9 & 16.3 & 16.8 & $16 . .2$ & 16.6 & 16.2 & 16.5 \\
\hline Metabolizable energy (Kcal/g) & 2.62 & 2.61 & 2.59 & 2.61 & 2.58 & 2.61 & 2.62 \\
\hline
\end{tabular}

$\mathrm{RJB}=$ Raw Jack beans, $\mathrm{RBG}=$ Raw bambara groundnuts, $\mathrm{RBS}=$ Raw benne seeds 


\section{Experimental birds and management}

A total of one hundred and forty (140) exotic adult cockerels (Goldmine strain) of twenty four (24) weeks old were randomly distributed into seven dietary groups at the rate of twenty (20) birds per group. Each group was further divided into five (5) birds per replicate group. The birds were housed singly in battery cage compartments. Foods and water were served adlibitum, and the experiment were performed for 8 weeks.

\section{Histological examination}

At the end of the eighth week of the experiment, three birds per replicate group were fasted overnight and killed by cervical dislocation. The internal organs were dissected out and the liver, kidney, pancreas and testis were preserved in $10 \%$ formalin solution for histological examination. The tissues were trimmed and fixed in Bouin's fixative for $24 \mathrm{~h}$, embedded in wax and sectioned at $6 \mu \mathrm{m}$ with microtome (Leitz and Weszlar) and finally stained with haematoxylin and eosin. The lesions of the organs were carefully observed under a microscope.

\section{Results and Discussion}

The results obtained are summarized in Table 2 . Haemagglutinin and trypsin inhibitors were higher in raw jack beans (RJB) than the raw bambara groundnuts (RBG) while no presence of the two antinutrients was obtained in the raw benne seeds (RBS) in this study. A canavanine content of $26.9 \mathrm{mg} / \mathrm{g}$ was obtained in the $R \mathrm{JB}$ while no presence of the antinutrient was detected in RBG and RBS, respectively. Trypsin inhibitor (TI) was not present in the RBS. Tannin, phytate and oxalate contents were higher in RBS. These observations are consistent with the findings of Essien and Udedibie (2007), Lutz and Prytulski (2008), Mamputu and Buhr (1991) and Rubio et al., (2003) respectively. The presence of high amount of haemagglutinin in jack beans signifies poor nutritional value as well as high toxicity when fed to cockerels in the raw form. Haemagglutinins have been reported to induce anorexia, prostration and even deaths in rats (Akanji et al., 2008). The relatively high TI activity obtained in RJB limit its usefulness as a source of protein for cockerels. Tannin, phytate and oxalate contents obtained in the RBS in this study were higher than values reported on various grain legumes (Apata,1990). Moreover, Lutz and Prytulski (2008) were of the opinion that phytic acid and oxalic acid have the ability to chelate several mineral elements and thereby reducing their availability in the intestinal tract.

Table 2. Antinutritional factors in raw jack beans, bambara groundnuts and benne seeds

\begin{tabular}{|c|c|c|c|}
\hline $\begin{array}{l}\text { Antinutritional } \\
\text { factors }\end{array}$ & $\begin{array}{l}\text { Raw jack } \\
\text { beans }\end{array}$ & $\begin{array}{l}\text { Raw } \\
\text { bambara } \\
\text { groundnuts }\end{array}$ & $\begin{array}{l}\text { Raw } \\
\text { benne } \\
\text { seeds }\end{array}$ \\
\hline Canavanine (mg/g) & 26.9 & & \\
\hline $\begin{array}{l}\text { Haemagglutinin } \\
\text { (g/seed) }\end{array}$ & $13,497.9$ & 941.3 & \\
\hline $\begin{array}{l}\text { Trypsin inhibitor } \\
\text { (g/seed) }\end{array}$ & $1,675.3$ & 380.4 & \\
\hline Tannin (g/100gdm) & 0.4 & 0.4 & 2.4 \\
\hline Oxalate (g/100gdm) & 0.4 & 0.2 & 2.4 \\
\hline Phytate (g/100gdm) & 0.7 & 0.3 & 5.2 \\
\hline
\end{tabular}

The results on the histological lesions in the organs of the cockerels are presented in Table 3. The livers from the birds fed control diet showed no visible lesions. However, there were extensive multifocal and lymphocytic infiltration with necrosis of hepatocytes of livers of birds fed $25 \%$ RJB and 50\% RJB respectively. Moreover, while slight lesions were obtained in birds fed 25\% RBG and $25 \%$ RBS, those fed $50 \%$ RBG showed severe hepatic congestion and extensive hepatic necrosis, respectively.

No visible lesions were observed in the pancreas from birds fed control diet and RBS based diets. However, the pancreas from birds fed RJB and RBG showed necrosis of glandular cells, lymphoid aggregates, thickening of the supporting stroma and multifocal interstitial lymphocytic infiltration. The kidneys from birds fed on control diet, $25 \%$ RBG, $25 \%$ RBS and 50\% RBS showed no visible lesion. However, the kidneys from birds fed $25 \%$ RJB and 50\% RJB and 50\% RBG showed widespread lymphocytic infiltrations of the renal interstitium.

In the testes of birds fed $25 \%$ RJB and $50 \%$ RJB, extensive degeneration of the seminiferous tubular epithelia cells with widespread interstitial lymphocytic infiltrations of the stroma was observed. The testes from birds fed 25\% RBG 


\section{Plant toxicology on cockerel organs}

and 50\% RBG and 50\% RBS showed moderate degeneration of seminiferous epithelium, respectively. No visible lesions were however obtained in testes of birds fed control diet and $25 \%$ RBS, respectively. The lesions in the livers, pancreas and kidney in the birds fed $25 \%$ RJB and $50 \%$ RJB and 50\% RBG showed similarities with those reported by Aletor and Fetuga (1984b) and Ologhobo et al., (1993). The multifocal aggregations of lymphoid cells of liver, lymphocytic infiltrations of the renal insterstitium of kidney, and pancreatic necrosis are clear indications of malfunctioning of the body organs thus with a likely occurrence of poor growth and even death in the birds upon long term consumption of the raw legumes.

Table 3. Histopathological lesions of organs of exotic adult cockerels fed raw jack beans, bambara groundnuts and benne seeds

\begin{tabular}{|c|c|c|c|c|c|c|c|c|}
\hline Organs & Lesions & Control & $\begin{array}{l}25 \% \\
\text { raw jack } \\
\text { beans }\end{array}$ & $\begin{array}{l}50 \% \\
\text { raw jack } \\
\text { beans }\end{array}$ & $\begin{array}{l}25 \% \\
\text { raw bambara } \\
\text { groundnuts }\end{array}$ & $\begin{array}{l}50 \% \\
\text { raw } \\
\text { bambara } \\
\text { groundnuts }\end{array}$ & $\begin{array}{l}25 \% \\
\text { raw } \\
\text { benne } \\
\text { seeds }\end{array}$ & $\begin{array}{l}50 \% \\
\text { raw } \\
\text { benne } \\
\text { seeds }\end{array}$ \\
\hline \multirow[t]{3}{*}{ Liver } & Congestion & - & ++ & ++ & ++ & ++ & ++ & ++ \\
\hline & Necrosis & - & ++ & ++ & - & ++ & - & - \\
\hline & Degeneration of hepatocytes & - & ++ & ++ & $1 / 2$ & ++ & - & - \\
\hline \multirow[t]{2}{*}{ Kidney } & Congestion & - & ++ & ++ & - & ++ & - & - \\
\hline & Hyperimia & - & + & ++ & M & + & - & - \\
\hline Pancreas & Hypertrophy and necrosis & - & + & ++ & + & ++ & - & - \\
\hline Testis & $\begin{array}{l}\text { Degeneration of } \\
\text { seminiferous epithelial cells }\end{array}$ & - & + & ++ & + & + & + & + \\
\hline
\end{tabular}

Different symbols indicate ++ , present but distinct; $\quad+$, present but moderate; $1 / 2$, present but less marked than usual; $M$, minimal or doubtful; -, no visible lesion.

The presence of histological lesions was less marked in birds fed RBS and this could be attributed to nonexistence of haemagglutinin and trypsin inhibitor activities. The severe histological lesions especially in birds fed 50\% RJB could be attributed to the combined effects of canavanine, haemagglutinin and trypsin inhibitor activities. According to Russell et al., (2008), haemagglutinin alone can interfere with some metabolic processes in the liver and cause intensive inflammation with destruction of epithelial cells.

On the mechanism of canavanine toxicity in monogastrics and even rats, D'Mello (1993), reported a catabolism of the toxic antinutritional factor into another toxic compound, canaline, with a negative effect on the liver through a decrease in hepatic ornithine decarboxylase and a subsequent accumulation of ornithine in body fluids. Crine and Lemieux (1982) also reported an incorporation of canavanine into liver enzymes of rats, thereby yielding proteins with reduced activity.

The extensive degeneration of the seminiferous tubular epithelia cells with widespread interstitial lymphocytic infiltrations of the stroma of testes of birds fed RJB in this study are an indication of reduction in semen characteristics and quality. Nutritional toxicity has been reported to affect spermatogenesis, which subsequently reduces sperm concentration (Akanji et al., 2007). In a study carried out by Yousef et al., (1995), rabbits were fed with food containing toxic carbofuran and glyphosate and there were reductions in sperm concentration as a result of direct cytotoxic effects on spermatogenesis and/or indirectly via hypothalami - pituitary - testis axis, which controls the reproductive efficiency. Goldman et al. (1990) also found the chlordimeform (toxic substance) caused decreases in the concentrations of serum gonadotropins and testosterone in rats. 


\section{Conclusion}

The results presented clearly demonstrate that the potentials of RJB, being the most toxic of the three plant seeds in this study, are limited by the presence of toxic antinutritional factors when fed to the cockerels either at $25 \%$ or $50 \%$ levels . On the other hand, the lesions observed in the organs from birds fed RBG and RBS showed lower level of toxicity when compared to jack bean. These findings clearly demonstrate the RJB, RBG and RBS need to be adequately processed before being fed to cockerels. Use of different processing methods for grain legumes and oil seeds has

\section{References}

Akanji AM, Ogungbesan AM, Emiola IA (2008). Relative effects of raw jack beans, bambara groundnuts, and benne seeds on semen quality of exotic adult cockerels. International Journal Of Food And Agricultural Research 5: 23-35.

Akanji AM, Ologhobo AD, Emiola IA (2007). Utilization of some raw tropical legumes in diets of exotic adult cockerels. Journal of Animal and Veterinary Advances 6. (4):485-489.

Akanji AM (2002). Enhancing the utilization of some tropical legume seeds in diets of exotic meat - type and egg - type chickens. PhD thesis, University of Ibadan. Pp 103-109.

Aletor VA, Fetuga BL(1984b). Effect of graded levels of raw lima bean (Phaseolus lunatus) on some liver enzyme activity in the rat. Nutr. Report Inter. 29: $565-570$.

Aletor VA, Fetuga BL (1988). Dietary interactions of lima bean (Phaseolus lunatus) trypsin inhibitor, haemagglutinin and cyanide. Effect on growth performance, nitrogen utilization and physiopathology on growing albino rats. Journal of Animal physiology and Nutrition 60: 113 115.

AOAC (1984). Official methods of analysis ( $\left.14^{\text {th }} \mathrm{ed}.\right)$. Association of Official Analytical Chemists, Washington, D. C.

Apata DF (1990).Biochemical, Nutritional and Toxicological assessment of some tropicalseeds, Ph.D. Thesis, University of Ibadan, Nigeria.

Bence AK, Crooks PA (2003). The mechanism of Lcanavanine cytotoxicity arginyl tRNA synthetase as a novel target for anticancer drug discovery. J. Enzyme Inhib. Med. Chem. 18 (5) : 383-94.

Chowdhury SR, Smith TK (2004).The effects of feeding blends of grains naturally contaminated been reported by different investigators. D'Mello and Walker, (1991) reported on the use of autoclaving method alone or together with the use of potassium bicarbonate $\left(\mathrm{KHCO}_{3}\right)$ at detoxifying jack bean. Also, Leon et al., (1991), Udedibie and Carlini,(1998) and Akanji (2002) reported on the efficacies of extrusion, dry urea treatment plus toasting and aqueous heating at destroying the haemagglutinin and trypsin inhibitor contents in raw grain legumes, respectively. Lutz and Prytulski (2008) also reported on the use of dehulling at reducing the tannin, oxalate and phytate contents located in the hulls of oil seeds.

with Fusarium mycotoxins on performance and metabolism of laying hens. Poultry Science. 83: $1849-1856$.

Crine, P, Lemicux E (1982). Incorporation of canavanine into rat pars intermedia proteins. Journal of Biological Chemistry 257: 832-838.

D'Mello JPF, Walker AG (1991): Detoxification of jack beans (Canavaliaensiformis) for young chicks. Animal Feed Science and Technology. 33 : $117-120$.

D'Mello JPF (1993). Non - protein amino acid, Canavalia ensiformis and hepatic ornithine decarboxylase. Amino acids. 5: 127-132.

Essien CA, Udedibie ABI (2007). Effect of two stage cooking on haemagglutinin and antitryptic activity of jack bean and its nutrition value for young growing rabbit. Proceedings of Nigerian Society For Animal production. 32: 192-194.

Goldman JM, Cooper RL, Laws SC, Rehnbers GL,Edwards TL, McElrvy WG, Hein JF (1990). Toxic effects of chlordimeform on serum gonadotropins in rats. Journal of Environmental Science and Health B30 (4) 513-534

Grant G, Moore L, Mckenzie NH, Stewart.JC, Putsztai A(1991). A survey of the nutritional and haemagglutinin properties of legume seeds generally available in the UK. British Journal of Nutrition. 50: 207 - 214.

Leon AM, Caffin JP, Plassart M, Picard M.L (1991). Effects of con A form jack bean seeds on short term food intake regulation in chicks and lying hens. Animal Feed Science and Technology. 33: $118-126$.

Lutz C,Pryztulski K (2008). Nutrition and Diet Therapy. $4^{\text {th }}$ Ed. Jaypee brothers medical Publishers. New Delhi pp 312. 
Mamputu M, Buhr RJ (1991). Effects of substituting sesame meal for soybean on layer performance. Poultry Science, 70 (suppl 1):77.

Natelson, S, Bratton, GR. (1984) Canavanine assay of some alfalfa varieties. Practical procedure for canavanine preparation. Micro Chemical Journal, $29: 2643$.

Olkowski AA, Olkowski BI, Amarowicz R, Classen HL (2004). Adverse effects of dietary lupine innbroiler chickens. Poultry Science, 80 : 621625.

Ologhobo AD, Apata DE, Oyejide. A (1993). Utilization of raw jack bean(Canavalia ensiformis) and jack bean fraction in diets for broiler chicks. British Poultry Science 34: 323 337.

Rubio LA, Brenes A, Centeno C (2003). Effects of feeding growing broiler chickens with practical diets containing lupin (Lupinus angustifolus) seed meal. British Poultry Science 44 (3) : 291307.

Russell RJ, Kerry PS, Stevens DJ, Steinhauer DA, Martin SR, Gamblin SJ, Skehel JJ (2008). Structure of influenza hemagglutinin in complex with an inhibitor of membrane fusion. Proc. Na Academy of Sciences, USA. 105 (46): 1773641.
Sahin K, Kucuki O, Sahin N (2001). Effects of dietary chromium picolinate supplementation on performance and plasma concentration of insulin and corticosterone in laying hens under low ambient temperature. Journal of Animal Physiology and Nutrition, 85: $142-147$.

Udedibie ABI, Carlini CR. (1998). Canavalia ensiformis seeds - A review. Animal Feed Science Technology 74: $95-106$.

Valdebouze P, Bergezone E, Gaborit, T, Desort LJ (1980). Content and distribution of trypsin inhibitors and haemagglutinin in some legume seeds. Canadian Journal of Plant Science 60: 695-701.

Van Oort MG, Hamel RJ, Slager, E.A (1989). The trypsin inhibitor assay. Improvement of an existing method. Proceedings of workshop on antinutritional factors in legume seeds. (Wegenigen. The Netherlands) Pp 80-86.

Wheeler EH, Ferrel, RE (1971). A method for phytic acid determination in wheat and wheat fractions. Cereal Chemistry. $48: 312-320$.

Yousef MI, Salem MH, Ibrahim HZ, Helmi S, Seehey MA, Bertheussan K (1995). Toxic effects of carbofuran and glyphosate on semen characteristics in rabbits. Journal of Environmental Science and Health B30 (4): 513-534. 